\section{Slipjoint of armored tube}

To the Editor: Ken Nakatani

Department of Pediatric Anesthesia and Critical Care Medicine, Okinawa Southern Medical Center and Children Medical Center
(118-1 Aza-arakawa, Haebaru-cho, Shimajiri-gun, Okinawa 901-1193, Japan)

J Jpn Soc Intensive Care Med. 2007;14:620 621.

\title{
水腎症に合併した急性腎孟腎炎：見逃さないコツ
}

\section{編集委員長殿}

本誌 14 巻 3 号で報告された皆川らの論文は, 中年女 性に発生した，急性腎孟腎炎およびそれに引き続いた 敗血症性ショックについての非常に示唆に富む症例報 告である1)。急性腎盐腎炎では, 高熱・悪寒などの全身 症状，および costovertebral angle (CVA)の吒打痛と いった理学所見が診断に有用であることは広く知られ ているが，これらの所見がそしい症例も少なからず存 在することは意外と知られていない2)。言葉を換えれ ば，たとえ臨床的な所見がそしくても，急性腎血腎炎 を容易に否定することができないということ，これが 第一に認識すべき重要な点であると思われる。

尿検査の所見がそしかったことは，診断を難しくし たようである。本症例で尿検査所見がそしかったのは, 尿管結石による尿路の閉塞のために「感染尿」が膀胱 に流入しなかったためと考えられる。これを裏付ける ように，細菌培養では血液，腎孟尿が陽性であったに もかかわらず, 膀胱カテーテル尿は陰性であった。こ のように，尿路の閉塞を伴う場合，尿検査所見が陰性 になることがあるということも，意外に知られていな い重要な事実である2),33。

本症例は結石により発生した水腎症に感染が加わり 急性腎孟腎炎に至ったものと考えられるが，このよう に水腎症が基礎にある急性腎孟腎炎は，一般の急性腎 跙腎炎と臨床所見が多少異なることが知られている2)。

臨床症状 - 理学所見, 臨床検査所見などから, 水腎 症などの基礎疾患を伴わない単純性の急性腎孟腎炎の 診断は一般に容易であり，画像診断を必要としないこ とが多い。しかし，適切な抗生物質投与に反応しない 場合, 急性腎孟腎炎を繰り返す場合, はっきりと診断
できない場合などは, 尿路結石や水腎症, 先天性尿路 奇形などの基礎疾患検索のため，何らかの画像診断が 必要であるといわれている。すなわち, 非典型的な経 過をたどる症例では「複雑性」の急性腎孟腎炎を疑っ て, 検査を進めるべきである。また糖尿病患者, acquired immunodeficiency syndrome (AIDS) 患者, 腎移植患 者など免疫能の低下した状態では, 腎膿瘍や腎周囲膿 瘍を併発するリスクが高いため，早めに画像診断でこ れらの病態をチェックした方がよいとされている。画 像診断として, CTは腎実質の状態や周囲の状態, 腹部 全般の状態を描出するうえで最も優れていると考えら れている3)。そのうえ, 閉塞部位の診断, ガスの存在 (気腫性腎炎など)，尿管壁や腎孟壁の肥厚，腎周囲の 状態, 反応性の胸水や腹水の状態, 周囲臓器の状態な どを客観的に描出できることから，その患者の「状態 の把握」という意味でも非常に有用である $31 。$

超音波検査は, 画像診断という意味では, 腹部臓器 を低侵襲で手軽に施行することができる4)。客観性にや や欠ける点, (たとえ拡張していても) 尿管の描出がご く一部分しかできない点, 肥満・腹部ガス・肋骨など の構造物により検査が困難になる点などの短所もある が，スクリーニングという意味ではまず行うべき検査 であると思われる。ただし，急速に発生した閉塞の場 合，拡張が軽微であることがあり，超音波検査ではよ く分からないこともある。

Intravenous pyelography (IVP) や drip infusion pyelography（DIP）に関しては，本症例のように水腎 症に合併しており（長期にわたる閉塞などにより）腎 機能自体が低下しているような場合は，十分に造影さ 
れないため診断的価値は乏しいと考えられる4)。閉塞部 の質的診断(例えば結石によるものなのか, 腫瘍による ものなのか)については, 全身状態が許せば, やや侵襲 的であるが順行性腎孟造影 (antegrade pyelography, AP) や逆行性腎盂造影 (retrograde pyelography, RP) の方が情報量の多いことがしばしばである。IVPやDIP は, 超音波検査の結果や全身状態などを考えて施行す べきであろう。

さて，本症例では初期の段階で身体所見や尿検査所 見に乏しく，症状が急速に悪化したことから，CTが撮 影された。超音波検査の所見で水腎症を認めたことか ら，尿路の閉塞があったことが容易に想像される。一 方で，(症例本文の記述によれば）入院当初に撮影した 腹部X線写真で結石が見つからなかったことから，閉 塞の機序をより正確に短時間に調べるためには CT が 最も優れていたと思われる。CT 撮影する前の時点で は，身体所見・尿検查所見に乏しく，尿路感染症が強 く疑われるような状況ではなかったようなので，他の 感染源を検索するという意味でも CT は有用であった と考えられる。

入院当初に撮影した腹部 $X$ 線写真で結石が見つから なかったことに関しては，腹部X線写真では小さな結 石であった場合やわずかな撮影条件の違いにより，腹 部ガスや骨と重なってしまい，結石像がはっきりしな くなることはしばしば経験することであり，慎重な対 応を要するものと考えられる。特に, 腹痛の症状が少 ないような症例では，「疑いの目」で見ないと読影しに くいことから，小さな結石を見落とす可能性がやや高 まると思われ，注意が必要である。このような意味で もCT は重要であると考えられる。

以上，急性腎盄腎炎の診断に関し，いくつかの注意 すべき pitfall が存在することを述べた。最後に，尿管
結石に伴う急性腎孟腎炎は，頻度は少ないものの，決 して稀な病態ではない。重症感染症の際は，仮に尿検 查所見・身体所見に乏しくても，鑑別診断として常に 念頭に置くべき病態であることを強調したい。このこ とが急性腎盂腎炎を見逃さない最も重要なコツではな いかと思う。

\author{
久米 春喜 \\ 東京大学医学部附属病院泌尿器科 \\ （于 113-8655 東京都文京区本郷 7-3-1） \\ 文 献
}

1) 米満弘一郎, 定光大海, 西野正人. 重症急性腪炎を契機に発 症し，ボリコナゾールの経腸投与が有効であったカンジダ 属敗血症の1例. 日集中医誌. 2007;14:339-40.

2) Schaeffer AJ. Upper tract infections, Infections of the urinary tract. In: Walsh PC, ed. Campbell's Urology, 8th ed. Philadelphia: Saunders; 2002. p. 551-67.

3) Kawashima A, Sandler CM, Goldman SM. Imaging in acute renal infection. BJU Int. 2000;86:70-9.

4) Colemen BG, Arger PH, Mulhern CB Jr, et al. Pyonephrosis: sonography in the diagnosis and managemanet. AJR Am J Roentgenol. 1981;137:939-43.

受付日 2007 年 6 月 5 日 採択日 2007 年 6 月 22 日

\section{Acute pyelonephritis associated with hydro- nephrosis: pitfalls of diagnosis}

To the Editor: Haruki Kume

Department of Urology, The University of Tokyo Hospital (7-3-1 Hongo, Bunkyo-ku, Tokyo 113-8655, Japan)

J Jpn Soc Intensive Care Med. 2007;14:621 622. 